UNIO - EU Law Journal. Vol. 3, No. 2, July 2017, pp 57-71.

®2017 Centre of Studies in European Union Law

School of Law - University of Minho

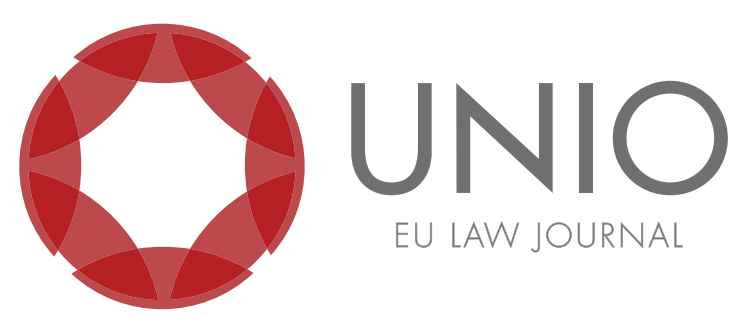

\title{
Companies' human rights compliance: the EU integrated approach to support the duty to assess and address human rights related risks of business activities
}

\section{Marta Gatti*}

ABSTRACT: The purpose of this article is, on the one hand, to describe EU support of the adoption of a corporate social responsibility policy by EU undertakings, both within and outside the EU borders. On the other hand, this article will focus on the most recent developments in the field of buman rights reporting at national level and, in particular, on the French commitment to implement mechanisms to prevent infringements on buman rights across the supply chain.

KEYWORDS: sustainable development - EU corporate social responsibility - buman rights protection - business and human rights.

\footnotetext{
* PhD student in European Union Law in the Law Department of the University of Verona.
} 


\section{Businesses' enterprise responsibility to respect human rights}

The ongoing globalization and the process of world trade liberalisation and economic deregulation entail numerous effects, even contradictory, related to the increased trade and financial flows, the creation of jobs and the transnational transfer of knowledge and technology. In this framework, economic actors have acquired increased powers and have contributed to the shift of responsibilities from States to non-states actors, namely markets and corporations, with direct impacts on sensitive and contentious issues, such as human rights and environmental protection.

This means that, while states, according to national and international law, have "primary responsibility to promote, secure the fulfilment of, and protect buman rights", transnational corporations and other enterprises, regardless of their size, location and structures, "within their respective spheres of activity and influence" are asked to comply with the rights on which they may have an impact. ${ }^{2}$

Although undertakings have no direct obligations under international law, ${ }^{3}$ there is actually a growing set of soft-law provisions regulating their conducts, which also correspond to societal expectations.

In this context, the first universally accepted global framework aimed at addressing the interconnection between business activities and human rights protection are the United Nation Guiding Principles on Business and Human Rights (UNGPs), ${ }^{4}$ presented by the UN Special Representative for Business and Human Rights, John Ruggie and adopted by consensus in the United Nations Human Rights Council in 2001. The Guiding Principles, which are the result of a long UN effort to create global social and environmental standards for enterprises, prioritise three interdependent pillars: First, the States' duty to prevent human rights abuses; Second, the business' enterprises responsibility to respect human rights and lastly, the States' responsibility to provide access to a remedy. Considered as a watershed event, since they put human rights concretely on the business agenda, the UNGPs are addressed both, to states and to enterprises and define the obligations and policies that have to be pursued to guarantee the protection of human rights at a national and international level.

The aim of this paper is to focus on the second pillar, that is the business enterprises' duty to avoid people' $s$ human rights being hurt because of their economic activities and relationships and to address negative impacts that occur. The core of this obligation is the setting of an ongoing process of human rights due diligence, which examines both undertakings' internal and external operations

\footnotetext{
${ }^{1}$ United Nations Economic and Social Council, Norms on the responsibilities of transnational corporations and other business enterprises with regard to human rights, E/CN.4/Sub.2/2003/12/ Rev.2 26 August 2003, 1, https://documents-dds-ny.un.org/doc/UNDOC/GEN/G03/160/08/ PDF/G0316008.pdf?OpenElement.

${ }^{2}$ Ibid., 4.

${ }^{3}$ An attempt was made in 2003 at the UN level, with the adoption, by the UN Sub-Commission on the promotion and protection of human rights, of the UN Norms on the Responsibility of Transnationals Corporations and other Business Enterprises with regard to human rights. These norms were however rejected by the UN Commission on human rights.

${ }^{4}$ Human Rights Council, Report of the Special Representative of the Secretary General on the issue of human rights and transnational corporations and other business enterprises, John Ruggie. Guiding Principles on Business and Human Rights: Implementing the United Nations "Protect, Respect and Remedy" Framework, A/HRC/17/31.
} 
that may raise human rights actual and potential risks ${ }^{5}$ and identifies the company's resources that could help to address them. ${ }^{6}$

The UNGPs are accompanied by a series of international and regional initiatives aiming at facilitating enterprises to comply with this procedure. One of these is the UN Global Initiative, a forum of discussion for government, companies and labour organizations that, in 2004, launched ten principles concerning human rights, labour, the environment and anti-corruption for business activities. Along with the UN commitment, other international organisations and bodies have elaborated principles concerning enterprises and human rights policies: the Organization for Economic Co-operation and Development ${ }^{7}$ and the International Labour Organization ${ }^{8}$ are only few examples. Among the most recent action, the Recommendations on climate-related financial disclosure, released by an industryled Task Force established by the Financial Stability Board ${ }^{9}$ could be mentioned. Furthermore, some non-governmental organizations, such as the Global Reporting Initiative, the International Integrated Reporting Council and, at a European level, the European Business Network for Corporate Social Responsibility, have translated these principles into practical guidelines and indicators, through which businesses report on their social performances.

It is worth noting that, however, it is namely, in the EU context, that enterprises are supported in their due diligence procedures. While the development of these procedures should be led by undertakings through the most suitable approach for enterprises themselves, the EU plays a pivotal role in the promotion of companies' human rights compliance programs. Therefore, the Union has conceived a mix of voluntary and regulatory measures, to facilitate responsible business conduct and provide for enterprises, a clear and predictable legal framework, promoting the adoption of appropriate compliance measures in more than one business sector.

\section{EU sustainable development and corporate social responsibility}

In 2016, on the fifth anniversary of the UNGPs adoption, the European Union confirmed that "business and buman rights continues to be very bigh" on its agenda. ${ }^{10}$

According to Article 2 of the TEU, the respect of human rights is one of the core values upon which the EU has been founded. This principle guides the Union

\footnotetext{
${ }^{5}$ For instance, the enterprise could cause negative impacts because of unsafe working conditions, or contribute to cause them if it pollutes water resources essential for local communities, or even be linked to negative impacts, if child labour is used by one of its subcontractors.

${ }^{6}$ In particular, according to the UNGPs, through the due diligence process the firm identifies, prevents, mitigates and accounts these risks, by involving potential affected groups and other relevant stakeholders (GP18), integrating the findings into its decision making (GP19), tracking the effectiveness of its responses (GP20), communicating internally and externally its policy (GP20), providing for remediation if it has caused (or contributed to) adverse impacts (GP22).

${ }^{7}$ OECD, OECD Guidelines for Multinational Enterprises, OECD Publishing, 2011, http://dx.doi. org/10.1787/9789264115415-en.

${ }^{8}$ ILO, Tripartite Declaration of Principles concerning Multinational Enterprises and Social Policy, 1977 (last amendment March 2017), http://www.ilo.org/wcmsp5/groups/public/---ed_emp/--emp_ent/---multi/documents/publication/wcms_094386.pdf.

${ }^{9}$ More information available at https://www.fsb-tcfd.org.

${ }_{10} 2016$ United Nations Forum on Business and Human Rights, Contribution of the European Union, https://eeas.europa.eu/sites/eeas/files/5th_forum_on_business_and_human_rights_-_eu_ contribution.pdf.
} 
also on the international scene, ${ }^{11}$ with specific reference to the common commercial policy, ${ }^{12}$ the field of the development cooperation, ${ }^{13}$ the humanitarian aid ${ }^{14}$ and the economic, financial, and technical cooperation with third States. ${ }^{15}$ Moreover, since the entry into force of the Treaty of Lisbon on December $1^{\text {st }} 2009$, the EU Charter of Fundamental Rights has the same legally binding force as the Treaties, ${ }^{16}$ setting a common framework of freedom and principles for Member States. Thus, the promotion and the enhancement of human rights protection in a wide range of different areas is one of the main goals of the EU, including (but not limited to) investment, trade, commercial, consumer protection and corporate law.

In order to enforce the protection of human rights, the EU has welcomed and endorsed the UNGPs. In particular, the Guiding Principles are actually one of the instruments that contribute to the implementation of the principle of Sustainable Development and of the strategy of Corporate Social Responsibility (CSR). ${ }^{17}$ The two concepts are, in fact, strongly connected with the issue of human rights applied to economic activities. ${ }^{18}$

According to the well-known definition given by the 1987 Brundtland Report, Sustainable Development is "development that meets the needs of the present without compromising the ability of future generations to meet their own needs". ${ }^{19}$ From the economic point of view, Sustainable Development should encourage undertakings to handle the consumption of energy and natural resources and thus, consider the impact of their operations on the ecosystem. In 2001, the EU implemented this objective through a Strategy for Sustainable Development, ${ }^{20}$ combining economic growth,

\author{
${ }^{11}$ See Article 21 TEU. \\ ${ }^{12}$ See Article 207(1) TFEU. \\ ${ }^{13}$ See Article 208(1) TFEU. \\ ${ }^{14}$ See Article 201(2) TFEU. \\ ${ }^{15}$ See Article 201(4) TFEU. \\ ${ }^{16}$ See Article 6 TEU. \\ ${ }^{17}$ The Commission Staff Working Document on Implementing the UN Guiding Principles on
} Business and Human Rights affirms the "proactive role" of the EU in supporting activities that can facilitate the progress of responsible conducts among "enterprises registered in the EU". Besides UNGPs, the Document specifies also that the EU recognises other main international tools, such as the UN Global Compact, International Organisation for Standardization (ISO) 26000 Standard on Social Responsibility, the International Labour Organization (ILO) Tripartite Declaration of Principles concerning Multinational Enterprises and Social Policy and the Organisation for Economic Co-operation and Development (OECD) Guidelines for Multinational Enterprises, as "support for businesses in addressing the UNGPs", SWD(2015) 144 final, 14 July 2015, https:/ / ec.europa. eu/anti-trafficking/sites/antitrafficking/files/swd_2015_144_f1_staff_working_paper_en_v2_ p1_818385.pdf).

${ }_{18}$ About the connection between sustainable development and corporate social responsibility see Karoly Behringer and Krisztina Szegedi, "The Role Of CSR In Achieving Sustainable Development - Theoretical Approach", European Scientific Journal, 12 (2016): 10-25. The authors argue that "the concept of Corporate Social Responsibility and that of Sustainable Development progressed separately for a long time. The business sphere got a larger and larger role in sustainable development and it has become clear by now that CSR contributes to the sustainable development of the business sphere and without that sustainable development cannot be attained".

${ }^{19} \mathrm{GH}$, Brundtland, and World Commission on Environment and Development. Our Common Future: Report of the World Commission On Environment and Development, Oxford: Oxford University, 1987, 3.

${ }^{20}$ European Commission, Communication from the Commission "A Sustainable Europe for a Better World: A European Union Strategy for Sustainable Development" (Commission's proposal to the Gothenburg European Council), COM/2001/0264 final, 15 May 2001, http:// eur-lex.europa.eu/legalcontent/EN/TXT/HTML/?uri=CELEX:52001DC0264\&qid=1495519833064\&from=EN. 
social cohesion and environmental protection in order to improve the quality of life in a long-term. With the entry into force of the Treaty of Lisbon, the principle of Sustainable Development has been introduced at EU Primary law level: therefore, it is one of the bases of the establishment of the Internal Market, ${ }^{21}$ as well as one of the values and interests that the Union promotes in its relations with the wider world. ${ }^{22}$ In its external action, the EU also aids the development of measures to preserve and improve the quality of the environment, in order to ensure Sustainable Development. ${ }^{23}$

As the Commission has noticed, enterprises could actively contribute to the EU's objectives of Sustainable Development through CSR, which offers a set of values on which to "base the transition to a sustainable economic system". ${ }^{24}$

The 2011 communication "A renewed EU strategy 2011-2014 for Corporate Social Responsibility" provides the notion of CSR, that is "the responsibility of enterprises for their impacts on society". The Commission adds that " [t]o fully meet their corporate social responsibility, enterprises should have in place a process to integrate social, environmental, ethical, buman rights and consumer concerns into their business operations and core strategy in close collaboration with their stakeholders". The aim is twofold: first, to maximize the creation of shared values through the development of "innovative products, services and business models that contribute to societal wellbeing" in a long-term approach and second, to adopt a due diligence strategy, "including through their supply chain".

The Commission has recently reaffirmed the link between the Sustainable Development and the CSR. In November 2016, the communication "Next Step for a Sustainable EU future" "25 aims at establishing a link between the Sustainable Development Goals (SDGs) set forth in the UN General Assembly's 2030 Agenda for Sustainable Development and the EU policy framework. In particular, the Commission associates the undertakings' compliance to human rights and environment protection on the one hand, to the eighth SDG, related to the promotion of decent work for all and inclusive and sustainable growth on the other hand. Moreover, it announces that it will intensify its work to promote the responsible conduct of business activities with concrete and effective actions, according to "the main principles and policy approach identify in the 2011 CSR Strategy". ${ }^{26}$

\section{EU voluntary guidance and general policy measures}

As to facilitate enterprises' duty to assess and address human rights related risks of their activities, the Commission is actively engaged in ensuring adequate

\footnotetext{
${ }^{21}$ See Article 3(2) TEU.

${ }^{22}$ See Article 3(2) TEU

${ }^{23}$ See Article 21(2)(f) TEU.

${ }^{24}$ European Commission, Communication from the Commission to the European Parliament, the Council, the European Economic and Social Committee and the Committee of the Regions, "Next steps for a sustainable European future. European action for sustainability", COM (2016) 739 final, 22 November 2016, 3, http://eur-lex.europa.eu/legal-content/EN/TXT/HTML/?uri=CELEX:52 016DC0739\&qid=1495520045859\&from $=\mathrm{EN}$.

${ }^{25}$ European Commission, Communication from the Commission to the European Parliament, the Council, the European Economic and Social Committee and the Committee of the Regions, "Next steps for a sustainable European future. European action for sustainability", $\operatorname{COM(2016)} 739$ final, 22 November 2016, http:// eur-lex.europa.eu/legal-content/EN/TXT/HTML/?uri=CELEX:5201 6DC0739\&qid $=1495520045859 \&$ from $=\mathrm{EN}$.

${ }^{26}$ Ibid., 11.
} 
assistance, through the elaboration of voluntary guidance, as well as of general policy documents.

In particular, guides for employment and recruitment agencies, ${ }^{27}$ information and communications technologies (ICT) ${ }^{28}$ and oil and gas companies ${ }^{29}$ were published in 2013, after stakeholder consultation. ${ }^{30}$ Moreover, the Commission has produced two guidance documents ${ }^{31}$ for EU small and medium enterprises, in order to give them advice about how they can adopt more responsible commercial practices. The aim of these guidelines is to apply the UN Guiding Principles on Business and Human Rights to the specific context and to offer practical advice, considering that the implementation of Corporate Social Responsibility depends on several factors, such as the size of the enterprise, its business model, the characteristics of its operation and the economic, social and environmental context in which it is located.

With regards to policy documents, instead, three main initiatives will be considered: two of them related to a specific sector, while the third one represents a comprehensive framework.

The first one is the "EU Strategy towards the eradication of trafficking in human beings" 32 launched by the Commission in 2012 and aimed at fighting modern slavery for sexual and labour purposes, forced marriage, illegal adoption and other forms of exploitation. One of the five priorities ${ }^{33}$ set by the strategy is dedicated to the increase of the prevention of trafficking in human beings through, among other actions, ${ }^{34}$ the promotion of the engagement of the private sector. Thus, CSR is one of the instruments considered as means to reduce the demand for all forms of trafficking,

${ }^{27}$ European Commission, Employment \& Recruitment Agencies Sector Guide on Implementing the UN Guiding Principles on Business and Human Rights, https://ec.europa.eu/anti-trafficking/ sites/antitrafficking/files/employment_and_recruitment_agencies.pdf.

${ }^{28}$ European Commission, ICT Sector Guide on Implementing the UN Guiding Principles on Business and Human Rights, https://www.ihrb.org/pdf/eu-sector-guidance/EC-Guides/ICT/ECGuide_ICT.pdf.

${ }^{29}$ European Commission, Oil and Gas Sector Guide on Implementing the UN Guiding Principles on Business and Human Rights, https://www.ihrb.org/pdf/eu-sector-guidance/EC-Guides/O\&G/ EC-Guide_O\&G.pdf.

${ }^{30}$ In particular, the three sector-specific human rights guidelines include indications concerning the development of policy commitment about the respect of human rights and its application to business relationships, the assessments of human right impact, the identification of actions able to prevent and mitigate potential negative impacts, the tracking of undertakings' performances and the building of a systematic plan of communication about human rights protection's measures and, eventually, the implementation of effective grievance mechanisms, aims at collecting complaints.

${ }^{31}$ European Commission, "My business and human rights. A guide to human rights for small and medium-sized enterprises" and "Tips and Tricks for Advisors. Corporate Social Responsibility for Small and Medium-Sized Enterprises".

${ }^{32}$ European Commission, Communication from the Commission to the European Parliament, the Council, the European Economic and Social Committee and the Committee of the Regions The EU Strategy towards the Eradication of Trafficking in Human Beings 2012-2016, COM(2012) 286 final, 19 June 2012, http://eur-lex.europa.eu/legal-content/EN/TXT/?qid=1500282301426\&uri= CELEX:52012DC0286.

33 The five priorities the EU should focus on to address the issue of human trafficking are: identifying, protecting and assisting victims of trafficking, stepping up the prevention of trafficking in human beings, increased prosecution of traffickers, enhanced coordination and cooperation among key actors and policy coherence, increased knowledge of and effective response to emerging concerns related to all forms of trafficking in human beings.

${ }^{34}$ In order to step up the prevention of trafficking in human beings, three main actions are envisaged: understanding and reducing demand, the establishment of a Private Sector Platform, EU-wide awareness raising activities and prevention programmes. 
including sexual exploitation. In practice, the strategy stimulates the implementation of due diligence procedures in the monitoring of labour standards, applied also to contracting and sub-contracting parties. To this end, the Commission funds projects aiming at improving compliance with anti-trafficking measures in sub-contracting and supply chains. ${ }^{35}$

The second document concerns the EU trade and investment policy. In 2013, the European Parliament, clarifying that "corporate social and environmental responsibility must become an integral part of the 'sustainable development' chapter of the EU's trade agreements", called on the Commission "to develop concrete proposals for the implementation of these CSR principles in trade policy". "Therefore, in 2015, the Commission, in the abovementioned Action Plan, confirmed the EU commitment to include in new trade and investment agreements provisions related to the respect of human rights. Moreover, it adopted the Communication "Trade for all: towards a more responsible trade and investment policy" to build a "more effective and more transparent" EU trade and investment policy. ${ }^{37}$ In the communication, the Commission promotes the reinforcement of "corporate social responsibility initiatives and due diligence across the production chain", respond to consumers' concerns and ensure the responsible management of global supply chains, the latter being the ultimate aim of the correspondence of EU trade and investment policy with EU values. Therefore, in these last years, the EU has negotiated a series of new generation bilateral agreements, containing not only classical provisions about the reduction of tariff and non-tariff barriers to trade in goods and services, but also provisions on sustainable development and on human rights (especially social protection of workers) and environment protection. ${ }^{39}$

Among the comprehensive trade agreements finalised after the 2013 Communication of the Commission, the Comprehensive Economic and Trade Agreement (CETA) with Canada ${ }^{40}$ includes in the Preamble explicit reference to CSR. It states that the Parties encourage "enterprises operating within their territory or subject to their jurisdiction to respect internationally recognized guidelines and principles of corporate

\footnotetext{
35 European Commission, Study on comprehensive policy review of anti-trafficking projects funded by the European Commission. Final Report, HOME/2014/ISFP/PR/THBX/0052, 23 September 2016, 71 ff, https://ec.europa.eu/anti-trafficking/sites/antitrafficking/files/study_on_ comprehensive_policy_review.pdf.

${ }^{36}$ European Parliament, Report on Corporate Social Responsibility: promoting society's interests and a route to sustainable and inclusive recovery (2012/2097(INI)), A7-0023/2013, 10, http:// www.europarl.europa.eu/sides/getDoc.do?pubRef=-//EP//NONSGML+REPORT+A7-2013$0023+0+\mathrm{DOC}+\mathrm{PDF}+\mathrm{V0} / / \mathrm{EN}$.

37 European Commission, Communication from the Commission to the European Parliament, the Council, the European Economic and Social Committee and the Committee of the Regions, "Trade for All. Towards a more responsible trade and investment policy", COM (2015) 497 final, 14 October 2015, http://eur-lex.europa.eu/legal-content/EN/TXT/HTML/?uri=CELEX:52015DC0 497\&qid=1495525073453\&from $=\mathrm{EN}$.

${ }^{38}$ Ibid., 14.

${ }^{39}$ About CSR in trade agreement please see Rafael Peels, Elizabeth Echeverria M., Jonas Aissi and Anselm Scheir, ILO Research Paper No. 13, Corporate social responsibility in international trade and investment agreements: implication for states, business and workers, 2016, http://www.ilo.org/wcmsp5/groups/ public/---dgreports/---inst/documents/publication/wcms_476193.pdf.

${ }^{40}$ The European Commission has adopted on 5 July 2016 draft proposals for Council Decisions on the signature, provisional application and conclusion of the CETA and submitted this to the Council for adoption. The agreement was signed on 30 October 2016 and the European Parliament gave its consent to CETA on 15 February 2017. The agreement will be applied provisionally after Canada will have notified adoption of all necessary legislative acts.
} 
social responsibility, including the OECD Guidelines for Multinational Enterprises, and to pursue best practices of responsible business conduct'. This commitment is reinforced in Chapter 22 of the Agreement, dedicated to trade and sustainable development, aiming at enhancing the coherence between economic, social and environmental objectives. In particular, the Agreement encourages a bilateral dialogue on raw materials and on activities supporting CSR for responsible supply chain of materials form conflictaffected and high-risk areas. ${ }^{41}$

The Agreement between the parties to promote CSR, including the exchange of best practices, education and training activities and technical advice is envisaged also in EU- Vietnam Free Trade Agreement (FTA) ${ }^{42}$ and in EU-Singapore FTA, ${ }^{43}$ which include also specific chapters concerning trade and sustainable development. Unlike the previous one, however, these two agreements consider, as international reference standards, also the UN Global Compact and the ILO Tripartite Declaration.

About the commitments concerning sustainable development in FTAs, the European Court of Justice has recently ruled. In a long-awaited Opinion ${ }^{44}$ about the nature of the EU competence to conclude the EU-Singapore FTA, in fact, the Court has clarified that these provisions included in the Agreement fall within the Common Commercial Policy and, therefore, within the exclusive competence of the EU referred to Article 3,1 TFEU..$^{45}$ In particular, the Court has considered that Chapter 13 about Sustainable Development, forms an integrated part of the Common Commercial Policy ${ }^{46}$ and, above all, plays an essential role in the envisaged Agreement. ${ }^{47}$ On this issue, on the contrary, the Council, the Member States, as well as the Advocate General Sharpston, in her Opinion ${ }^{48}$ have considered that sustainable issues do not have specific links with international trade, thus EU competence was shared with Member States. ${ }^{49}$

The third policy document, which includes CSR indications, is finally the Action Plan of human rights and democracy for $2015-2019,{ }^{50}$ which aims at enhancing the protection of human rights in EU external policies. The Plan identifies five main goals to achieve through multiple actions. In particular, one of the objective is to advance business and human rights, by developing the capacity and the knowledge on the

\footnotetext{
${ }^{41}$ See Article 25(4) CETA.

${ }^{42}$ On 1 February 2017, the preliminary text of the Agreement was published and it has been submitted to the legal review. It will be presented to the Council for ratification and the European Parliament for consent in the second half of 2017.

${ }^{43}$ The draft agreement has to be formally approved by the European Commission and then agreed upon by the Council and ratified by the European Parliament.

${ }^{44}$ CJEU (Full Court), Opinion 2/15, 16 May 2017, http:// eur-lex.europa.eu/legal-content/EN/TX T/?qid=1500284259781\&uri=CELEX:62015CV0002(01).

45 Opinion 2/15, para. 167. According to para. 36, "an EU act falls within that policy if it relates specifically to such trade in that it is essentially intended to promote, facilitate or govern such trade and has direct and immediate effects on it'.

${ }^{46}$ Opinion 2/15, para. 147.

${ }^{47}$ Opinion 2/15, para. 162.

${ }^{48}$ AG Sharpston, Opinion delivered on 21 December 2016, Opinion 2/15, http://eur-lex.europa. eu/legal-content/EN/TXT/?qid=1500284259781\&uri=CELEX:62015CC0002(01).

${ }^{49}$ Opinion 2/15, para. 22.

${ }^{50}$ European Commission and the High Representative of the European Union for Foreign Affairs and Security Policy, Joint Communication to the European Parliament and the Council, Action Plan on Human Rights and Democracy (2015-2019). "Keeping human rights at the heart of the EU agenda”, JOIN(2015) 16 final, 28 April, 2015, http://eur-lex.europa.eu/legal-content/EN/TXT/ HTML/?uri=CELEX:52015JC0016\&qid=1495525951367\&from=EN.
} 
implementation of Business and Human Rights guidelines, ${ }^{51}$ and by raising awareness on CSR in external action and policy dialogue with partner governments and regional organisations. Furthermore, in order to foster better coherence and consistency of EU external action, the Plan reaffirms the EU's commitment to include, in new or revised trade and investment agreements with third countries, provisions related to the respect and fulfilment of human rights and provisions on CSR.

\section{EU regulatory initiatives}

Enterprises' compliance with social and environmental standards and human rights protection are supported and encouraged also trough EU legislative measures. In this framework, three of the most recent EU interventions will be considered: the revised Directive of Public Procurement, the Directive that obliges non-financial disclosure for large undertakings and the Regulation of international trade of minerals coming from unstable regions.

\subsection{Directives $2014 / 23,2014 / 24$ and $2014 / 25$ on public procurement}

The first EU regulatory instrument that will be considered is the package of three public procurement Directives, ${ }^{52}$ setting out the EU legal framework for procurement by public authorities, in compliance with the TFEU, the conditions of the WTO's Government Procurement Agreement, as well as bilateral trade agreements. The purpose of this regime is twofold. First, it is to open up the public procurement market and thus, ensure the free movement of supplies, services and works within the EU. On the other hand, it is to stimulate smart, sustainable, and inclusive growth; "while ensuring the most efficient use of public funds". ${ }^{53}$

This paper will focus in particular on Directive 2014/24, repealing Directive 2004/18, and on its dispositions, which are aimed at promoting green social and sustainable tenders. The Directive establishes procedures that must be followed in order to award a contract to suppliers, when its value exceeds set thresholds. ${ }^{54}$ Taking into account sustainability issues, its purpose is, firstly, to integrate environmental, social and labour requirements into public procurement procedures and, secondly, to foster Member States and contracting authorities to take all relevant measures in order to ensure compliance with obligations in the fields of environmental, social and labour law.

This means that the observance of the environmental, social and labour law provisions should be assessed at the relevant stages of the procurement procedures,

\footnotetext{
${ }^{51}$ In particular as regards the UN Guiding Principles on Business and Human Rights (UNGPs) and other tools and initiatives that contribute to the implementation of the UNGPs.

${ }^{52}$ Directive 2014/23/EU of the European Parliament and of the Council of 26 February 2014 on the award of concession contracts, http://eur-lex.europa.eu/legal-content/EN/TXT/?qid= 1500283061726\&uri=CELEX:32014L0023; Directive 2014/24/EU of the European Parliament and of the Council of 26 February 2014 on public procurement and repealing Directive 2004/18/ EC, http://eur-lex.europa.eu/legal-content/EN/TXT/?qid=1500283107938\&uri=CELEX:3201 4L0024; Directive 2014/25/EU of the European Parliament and of the Council of 26 February 2014 on procurement by entities operating in the water, energy, transport and postal services sectors and repealing Directive 2004/17/EC, http:/ / eur-lex.europa.eu/legal-content/EN/TXT/?qid=1500 283140331\&uri=CELEX:32014L0025.

${ }^{53}$ Recitals 1 and 2 of Directive 2014/24.

${ }^{54}$ Article 4 of Directive 2014/24.
} 
especially in the criteria for awarding contracts. Furthermore, the rejection of a tender should be mandatory in case of abnormally low prices resulting from noncompliance with mandatory EU law or national law in the field of social, labour or environmental law. In addition, contracting authorities wishing to purchase works, supplies, or services with specific environmental and social characteristics could require specific certifications or labels. ${ }^{55}$ Lastly, obligations stemming from international agreements ratified by all Member States and listed in Annex X of the Directive should also apply during contract performance to subcontractors.

Nevertheless, it is worth nothing that, in accordance with the Directive, the observance of social and environmental requirements is based essentially on selfdeclarations. Moreover, as Recital 45 of the Directive specifies, negotiations may concern all characteristics of the purchased works, supplies and services including social, environmental and innovative aspects. However, these aspects could not constitute minimum requirements to award the contracts, like physical, functional and legal issues.

In order to facilitate the inclusion of clear and verifiable social and environmental criteria for products and services in the public procurement process, the European Commission has elaborated a guidance clarifying how environmental considerations could be included at each stage of the procurement process. ${ }^{56}$ This voluntary instrument, called Green Public Procurement policy, provides specific indicators to high-impact sectors, such as buildings, food and catering services, road transport vehicles and energy-using products.

\subsection{Directive $2014 / 95$ on non-financial reporting}

The second important step in embedding into EU law the corporates' responsibility to respect human rights as it is expressed in the UNGPs, is represented by Directive 2014/95, which introduces new rules on the disclosure of non-financial and diversity information. ${ }^{57}$

The Directive mainly introduces the duty for some large undertakings to report from the 2017 financial years on the actions taken in the area of CSR, including due diligence procedures. In particular, it requires the disclosure of relevant and useful information on their policies, principal risks and results obtained in terms of environmental and social aspects, protection of human rights, fighting corruption and bribery. This information should be obtained through an internal due diligence procedure and should involve all suppliers and subcontractors, regardless of their dimension and their geographical origin, as well as all other stakeholders. The importance of the Directive is twofold. On the one hand, the coordination of national provisions concerning the

\footnotetext{
55 Article 43 of Directive 2014/24.

${ }^{56}$ Buying green! A handbook on green public procurement, $3^{\text {rd }}$ Edition, http://ec.europa.eu/ environment/gpp/index_en.htm.

${ }^{57}$ Directive 2014/95/EU of the European Parliament and of the Council of 22 October 2014 amending Directive 2013/34/EU as regards disclosure of non-financial and diversity information by certain large undertakings and groups, http://eur-lex.europa.eu/legal-content/EN/TXT/?qid=1 500282998751\&uri=CELEX:32014L0095. Members States should have implemented the Directive 2014/95 by 6 December 2016. Belgium, Ireland, Spain, Cyprus, Portugal and Slovenia have not proceeded in the transposition yet. For a complete analysis see Dániel Gergely Szabó and Karsten Engsig Sørensen, New EU Directive on the Disclosure of Non-Financial Information (CSR), Nordic \& European Company Law Working Paper, No. 15-01, 2015, available at SSRN: https://ssrn.com/ abstract $=2606557$.
} 
disclosure of non-financial information aims at enhancing the consistency and the comparability of human rights policies disclosed throughout the Union and to assure the free movement of persons, services and capital. ${ }^{58}$ In addition, the harmonisation of the discipline in this field avoids for undertakings having to be made to deal with extra costs if Member States have implemented different disclosure regimes. On the other hand, the Directive is deemed to answer to a long-term necessity, that is, a change towards a sustainable global economy through social and environmental protection, ${ }^{59}$ by affecting how business is conducted.

In this context, it is worth noting that the disclosure regulation aims at trying to promote CSR in a relatively non-intrusive way. Firstly, according to Article 19a,1 and 29a,1, undertakings obliged to disclose are Public Interest Enterprises ${ }^{60}$ within the EU, exceeding the average number of 500 employees during the financial years and parent undertakings of a group with more than 500 employees. In this last case, only the parent undertaking has to be a Public Interests Enterprises and its subsidiaries could be any kind of undertaking located also outside the EU. Thus, the Directive exempts smaller enterprises from the obligation to publish a non-financial statement, in order to avoid creating unnecessary costs and administrative burdens.

Secondly, the Regulation allows companies to adopt the CSR policy they favor, and even abstain for adopting those they wish to jettison. In this case, however, they have the duty to explain why, in a "clear and reasonable" way. ${ }^{61}$

Thirdly, Article 2 of the Directive enables the Commission to prepare non-binding guidelines on the methodology for reporting non-financial information, "including Key Performance Indicators, general and sectorial", by December 2016, in order to facilitate data collection and comparison. From 15 January to 15 April 2016, the Commission launched a public consultation to involve stakeholders and to collect their suggestions before the elaboration of the guidelines. The majority of the respondents stressed that guidelines should identify key principles, provide flexibility and refer to other existing frameworks, ${ }^{62}$ without duplicating them. In particular, stakeholders privileged a principle-based framework, instead of a pre-defined set of indicators, in order to respect the different needs of different companies. ${ }^{63}$ This approach was also endorsed by the European Parliament in its 2013 above-cited report on Corporate Social Responsibility, calling on the Commission not to introduce specific parameters, but to provide companies with and promote the use of international methodologies, "such as those of the Global Reporting Initiative and the International Integrated Reporting Council". ${ }^{64}$

\footnotetext{
${ }^{58}$ Ibid., recital 4 and 6.

${ }^{59}$ Ibid., recital 3.

${ }^{60}$ This means listed companies, banks, insurer and other undertakings so designated by the Member States.

${ }^{61}$ Ibid., Article 29a(2).

${ }^{62}$ Among others, the above-mentioned OECD Guidelines, the UNGPs and the ILO Tripartite Declaration.

${ }^{63}$ European Commission, Feedback statement on the public consultation on the non-binding guidelines for reporting on non-financial information by companies having taken place from 15 January to 15 April 2016, FISMA/B3, 20 September 2016, 18 ff, http://ec.europa.eu/finance/ consultations/2016/non-financial-reporting-guidelines/docs/summary-of-responses_en.pdf.

${ }^{64}$ European Parliament, Report on Corporate Social Responsibility: promoting society's interests and a route to sustainable and inclusive recovery (2012/2097(INI)), A7-0023/2013, 7, http:// www.europarl.europa.eu/sides/getDoc.do?pubRef=-//EP//NONSGML+REPORT+A7-2013$0023+0+\mathrm{DOC}+\mathrm{PDF}+\mathrm{V} 0 / / \mathrm{EN}$.
} 
On these bases, on 26 June 2017, the guidelines were released. ${ }^{65}$ As suggested, the Commission focused on six key principles that are intended to help companies draw up a fair, balanced, understandable, stakeholder-oriented, consistent and coherent nonfinancial statement.

Fourthly, in two cases, undertakings are allowed to hold back the disclosure of non-financial information. On the one hand, Member States could exempt undertakings when they publish the information required by Articles 19a,1 and 29a,1 following an alternative national or international framework, which corresponds to the same financial year. On the other hand, the non-financial statement can be omitted to protect commercial secrets, so as not to damage the undertaking's commercial position, i.e. during ongoing commercial negotiations. The last element to be considered is the enforcement mechanism is Articles 19a,5 and 29a,4. These Articles state that Member States should ensure that auditors "check whether the nonfinancial statement has been provided". This means that checking the content of these reports is not a mandatory requirement.

In order to promote the disclosure of non-financial information and CSR policies, the Italian legislative Decree 254/2016 ${ }^{66}$ implementing the Directive has set out the possibility for undertakings having less than 500 employees to produce and publish a voluntary report. In the event that this disclosure includes all the information required by the decree, the report could receive a "compliance certificate", 67 aiming at fostering the undertaking's accountability in the market.

\subsection{Regulation $2017 / 821$ on supply chain due diligence obligations for conflict minerals}

Regulation 2017/821 ${ }^{68}$ introduces supply chain due diligence obligations for EU importers of ores and concentrates containing tin, tantalum and tungsten, and gold originating from conflict-affected and high-risk areas ${ }^{69}$ In particular, EU importers are required to identify and address actual and potential risk, to prevent and mitigate adverse impacts associated with their sourcing activities, ${ }^{70}$ through a combination of voluntary supply chain due diligence procedures, tools and mechanisms, including independent third-party audits. ${ }^{71}$ The purpose of this legal instrument is to promote

\footnotetext{
${ }^{65}$ Communication from the Commission, Guidelines on non-financial reporting (methodology for reporting non-financial information), OJ C 215, 5 July 2017, p. 1-20, available at http://eur-lex. europa.eu/homepage.html.

${ }^{66}$ Decreto Legislativo 30 dicembre 2016, n. 254, attuazione della direttiva 2014/95/UE del Parlamento Europeo e del Consiglio del 22.10.2014, recante modifiche alla direttiva 2013/34/UE per quanto riguarda la comunicazione di informazioni di carattere non finanziario e di informazioni sulla diversità da parte di talune imprese e di taluni gruppi di grandi dimensioni, in Gazzetta Ufficiale della Repubblica Italiana, 7, 10 January 2017.

${ }^{67}$ Ibid., Article 7.

${ }^{68}$ Regulation (EU) No 2017/821 of the European Parliament and of the Council of 17 May 2017 laying down supply chain due diligence obligations for Union importers of tin, tantalum and tungsten, their ores, and gold originating from conflict-affected and high-risk areas, http://eur-lex. europa.eu/legal-content/EN/TXT/?qid=1500283246345\&uri=CELEX:32017R0821.

${ }^{69}$ The Regulation specifies (Article 2, let. d) that "conflict-affected and bigh-risk areas' means areas in a state of armed conflict or fragile post-conflict as well as areas witnessing weak or non-existent governance and security, such as failed states, and widespread and systematic violations of international law, including human rights abuses". Some examples are the Democratic Republic of Congo and the African Great Lake Region.

${ }^{70}$ Ibid., Article 1, d

${ }^{71}$ Ibid., Article 1, f.
} 
responsible sourcing, by breaking the link between mineral extraction and conflicts, considering that the exploitation of these kind of minerals is often one of the main sources of financing of armed groups that operate in high-risk areas.

The Regulation, which is based on the OECD Due Diligence Guidance for Responsible Supply Chains of Minerals from Conflict-Affected and High-Risk Areas, complements the EU regulatory measures on timber and timber product on the EU market ${ }^{72}$ and on international trade in rough diamonds, ${ }^{73}$ requiring EU operators to exercise due diligence in their supply chain.

It introduces a mandatory compliance of EU importers of these metals, with the exception of smaller operators. ${ }^{74}$ Moreover, companies that do not import directly from areas affected by conflicts but that use these minerals in their production chains are asked, on a voluntary basis, to report annually on their due diligence measures. Member State authorities are responsible for ensuring that companies comply with this obligation through appropriate ex-post checks $^{75}$ and for the elaboration of rules applicable to infringements. ${ }^{76}$

In order to ensure a uniform implementation of the Regulation, the Commission is asked, firstly, to identify the criteria and the methodology for the recognition of equivalence between due diligence independent measures already put in place by certain companies and the due diligence obligations set out in the Regulation, in order to "avoid double auditing". ${ }^{77}$ Secondly, to draft a list of EU responsible smelters and refiners suppliers ${ }^{78}$ and thirdly, to examine annual reports submitted by Member States on the implementation of the Regulation and to review, by 1 January 2020, the functioning and the effectiveness of the Regulation. ${ }^{79}$

\section{Recent developments in the field of human rights reporting at national level: the French commitment}

In this framework, the French government strongly committed to implement mechanisms to prevent infringements on human and environmental rights across the whole supply and production chain, especially following the events of the Rana Plaza collapse in 2013 and the deaths of more than 1000 textile workers in Bangladesh.

The French National Assembly ${ }^{80}$ has underlined the limited scope of the EU regulatory measures promoting CSR, as well as the inadequacy of the national

\footnotetext{
${ }^{72}$ Regulation (EU) No 995/2010 of the European Parliament and of the Council of 20 October 2010 laying down the obligations of operators who place timber and timber products on the market, http:/ / eur-lex.europa.eu/legal-content/EN/TXT/?uri=CELEX\%3A32010R0995.

${ }^{73}$ Council Regulation (EC) No 2368/2002 of 20 December 2002 implementing the Kimberley Process certification scheme for the international trade in rough diamonds, http://eur-lex.europa. eu/legal-content/EN/TXT/?qid=1500283493754\&uri=CELEX:32002R2368.

${ }^{74}$ Recital 18 specifies that the Regulation should not apply in situation where the Union importers' annual import volumes of each mineral or metal concerned are below the volume thresholds listed in Annex I.

${ }^{75}$ Ibid., Article 11.

${ }^{76}$ Ibid., Article 13

${ }^{77}$ Ibid., recital 14.

${ }^{78}$ Ibid., Article 9.

${ }^{79}$ Ibid., Article 17.

80 Assemblée Nationale, Rapport d’information déposé par la Commission des Affaires européennes, enregistré à la Présidence de l'Assemblée nationale le 13 mai 2015, http://www. assemblee-nationale.fr.
} 
initiatives for the promotion of social and environmental standards' compliance so far adopted. To this aim, it has encouraged the European Commission to submit a proposal in order to harmonise the EU Member States' commitment concerning CSR and has suggested the main features that this proposal should include. First, these new rules should apply to all enterprises, whatever their sector of activity, registered in one of the EU Members States. A threshold should be set, that could coincide with the one included in the above-mentioned Directive 2014/95. Second, the rules should be binding on multinational corporations for the conduct of their subsidiaries, subcontractors and suppliers. Thirdly, the proposal should impose effective and dissuasive sanctions, proportionate to the environmental, social or health damages caused by non-compliance behaviour.

The French initiative has been supported by seven other Parliamentary Chambers, ${ }^{81}$ which were involved in an inter-parliamentary meeting on CSR which was held in Paris in May 2016, chaired by Ms Danielle Auroi, President of the European Affairs Committee of the French National Assembly. ${ }^{82}$ The Committee sent its observations to the Commission, including the invitation to submit draft legislation implementing CSR principles at EU level.

In light of the foregoing, the main result of the French commitment is the recent entry into force of law No. 2017-399 on the duty of care of parent companies and ordering companies. ${ }^{83}$ The aims at introducing a duty on major groups of companies to care for their employees and their environment, including when subcontractors are located in countries that are less stringent in the protection of health, safety, human rights, or environment. The law specifically applies to large French companies registered in France with more than 5000 employees working for the company and its direct or indirect French-registered subsidiaries, or more than 10000 employees working for the company and in its direct or indirect subsidiaries globally.

Companies meeting these criteria are required to develop annual vigilance plans that should provide risks mapping and procedures for the assessment, on a regular basis, of the situation of subsidiaries, subcontractors, or suppliers with whom an established commercial relationship is maintained. Moreover, it should include a mechanism for alerting and collecting alerts on the existence or the realisation of risks, drawn up in consultation with the representative Trade Union organizations. Lastly, it should contain a mechanism for monitoring the measures implemented and evaluating their effectiveness.

The draft law had proposed civil fines for failure to comply of $€ 10$ million, that could reach as high as $€ 30$ million in cases of injuries that could have otherwise been prevented. However, after the request of several Members of Parliament about the law's compatibility with the French Constitution, the Constitutional Court clarified that "in view of the vagueness of the language used by the legislator in defining the obligations it created" the provision imposing a fine is unconstitutional. Therefore, a company cannot be fined if it does not establish a vigilance plan or does not comply with its vigilance plan. Despite the fact that the law seems to have lost much of its deterrent value, the breach

\footnotetext{
${ }^{81}$ Specifically, the assemble of the Portuguese Republic, the Latvian Parliament, the Italian Senate, the UK House of Lords, the Slovak Parliament, the Lithuanian Parliament and the Lower House of the Dutch Parliament.

${ }^{82}$ Minutes of the meeting could be found at http://www.senato.it/home.

${ }^{83}$ LOI n 2017-399 du 27 mars 2017 relative au devoir de vigilance des sociétés mères et des entreprises donneuses d'ordre, https://www.legifrance.gouv.fr/.
} 
of this duty of care may in any case harm the company's reputation.

\section{Concluding remarks}

The disclosure of non-financial information, the promotion of business responsible conduct in Member and non-Member States, especially in sensitive sectors, the practical implementation of UNGPs in cross-cutting issues and a CSR-oriented trade and investments policy are the main instruments through which the EU plays a supporting role in corporates' activities. In particular, CSR has a multifaceted nature that let, on the one hand, the enterprises develop their personal approach, appropriate to the circumstances, and, on the other hand, the Union to act through a mix of voluntary policy measures and, where necessary, complementary regulations.

As the European Parliament underlines, since the 2009 global economic crisis came from a lack of "transparency and responsibility", CSR could make a "great contribution" towards restoring lost confidence and accountability, if implemented correctly and by all firms, not only the larger ones. This could lead to a sustainable economic recovery and can "mitigate the social consequences of the economic crises". ${ }^{84}$ Therefore, the EU approach towards a flexible CSR could, on the one hand, improve the competitiveness of enterprises, by bringing benefits in terms of savings, access to capital and customer relationships. In other words, undertakings could build a long-term trust relationship with consumers, employees and citizens, which could facilitate enterprises' growth and innovation. On the other hand, through CSR, enterprises importantly, contribute to the EU's Treaty objectives of promoting sustainable development and ensuring the existence of a highly competitive social market economy.

To this end, EU engagement in this field is ongoing: a proposa ${ }^{85}$ for a Directive amending the Directive 2013/34/EU as regards disclosure of income tax information by certain undertakings and branches is current under negotiation within the Council. The proposal would promote a public scrutiny of the corporate tax system in order to ensure that profits are taxed effectively where they are generated and to reinforce public trust and strengthen companies' CSR by contributing to the welfare in the countries where they operate. Furthermore, the Commission decided, in October 2016, to establish a High-Level Expert Group on sustainable finance, working on a set of recommendations that would ground a comprehensive EU strategy on sustainable finance.

Despite its strong commitment, however, the Commission, in response to the above-mentioned invitation coming from the eight parliamentary chambers, has clarified that it has "no plans to adopt further legislation at this stage, but is carefully monitoring (...) how the situation is evolving in Member States". ${ }^{86}$

\footnotetext{
${ }^{84}$ European Parliament, Report on Corporate Social Responsibility: promoting society's interests and a route to sustainable and inclusive recovery (2012/2097(INI)), A7-0023/2013, 4, http:// www.europarl.europa.eu/sides/getDoc.do?pubRef=-//EP//NONSGML+REPORT+A7-2013$0023+0+\mathrm{DOC}+\mathrm{PDF}+\mathrm{V} 0 / / \mathrm{EN}$.

${ }^{85}$ European Commission, proposal for a Directive of the European Parliament and of the Council amending Directive 2013/34/EU as regards disclosure of income tax information by certain undertakings and branches, $\operatorname{COM}(2016) 198$ final, 12 April 2016, http://eur-lex.europa.eu/legalcontent/EN/TXT/HTML/?uri=CELEX:52016PC0198\&from=EN.

86 European Commission, C(2016) 8597 final, 15 December 2016, http://ec.europa.eu/ transparency/regdoc/.
} 